\title{
Deskripsi Keterampilan Proses Sains Peserta Didik dalam Pembelajaran Menggunakan Modul Sistem Koloid Berbasis Inkuiri Terbimbing
}

\section{Description of Science Process Skills for Students in Learning Using Guided Inquiry-Based Colloidal System Modules}

\author{
A Afikah ${ }^{1}$ and Iryani ${ }^{*}$ \\ 1 Pendidikan Kimia, Universitas Negeri Padang, Jl. Prof. Dr. Hamka, Air Tawar Barat, \\ Padang Utara, Sumatera Barat, Indonesia 25171 \\ *in.iryani@yahoo.co.id
}

\section{ARTICLE INFO}

Received 30 May 2020

Revised 25 June 2020

Published 03 July 2020

\section{QUICK GLOSSARIUM}

Penulis menggunakan singkatan-singkatan berikut pada artikel ini.

\begin{tabular}{r|l} 
IT & $\begin{array}{l}\text { Inkuiri } \\
\text { Terbimbing }\end{array}$ \\
\hline KD & Kompetensi Dasar \\
\hline KI & Kompetensi Inti \\
\hline KPS & Keterampilan \\
& Proses Sains \\
\hline LKPD & Lembar Kerja \\
& Peserta Didik \\
\hline $\mathbf{R}$ & (Skor) Rata-Rata \\
SD & Standar Deviasi
\end{tabular}

\begin{abstract}
The purpose of this study is to get an overview of the Science Process Skills of students in learning using the Guided Inquiry-based Colloidal System module. The type of research used is library research with descriptive analysis. The data used in this study are secondary data, i.e. scientific journals which are in the form of articles. The data collection method is in the form of a documentation method with data analysis techniques, namely content analysis. Based on the results of a journal review that has been done, it is obtained that the use of the Guided Inquiry-Based Colloidal System module in learning especially in practical activities can bring up the Science Process Skills of students well. Each Science Process Skill indicator appears with different percentages in either category.

\section{KEYWORDS}

Guided Inquiry-Based Modules, Science Process Skills, System Colloid

\section{ABSTRAK}

Tujuan penelitian ini untuk mendapatkan gambaran tentang Keterampilan Proses Sains (KPS) peserta didik dalam pembelajaran yang menggunakan modul Sistem Koloid berbasis Inkuiri Terbimbing (IT). Jenis penelitian yang digunakan yaitu penelitian kepustakaan (library research) dengan analisis deskriptif. Data yang digunakan pada penelitian adalah data sekunder yaitu jurnal ilmiah bereputasi berupa artikel. Metode pengumpulan data berupa metode dokumentasi dengan teknik analisis data yaitu analisis isi (content analysis). Berdasarkan hasil review jurnal yang telah dilakukan didapatkan hasil bahwa penggunaan modul Sistem Koloid yang berbasis IT dalam pembelajaran terutama pada kegiatan praktikum dapat memunculkan KPS peserta didik dengan baik. Setiap indikator KPS muncul dengan persentase yang berbedabeda dengan kategori baik.
\end{abstract}

\section{KATA KUNCI}

Keterampilan Proses Sains, Modul Berbasis Inkuiri Terbimbing, Sistem Koloid 


\section{PENDAHULUAN}

Kimia merupakan mata pelajaran pokok pada bidang studi Ilmu Pengetahuan Alam (IPA). Berdasarkan Kompetensi lulusan dari kurikulum 2013 revisi 2018 yang dijabarkan pada Kompetensi Dasar (KD) 2.1 tentang pentingnya perilaku ilmiah seperti memiliki rasa ingin tahu; objektif; jujur; teliti; tekun; hati-hati; bertanggung jawab; terbuka; kritis; kreatif; inovatif dan peduli lingkungan. Pada Kompetensi Inti (KI) 4 tentang kemampuan untuk menggali, mencoba, mengolah, dan menginterprestasikan data dalam ranah konkret dan abstrak. Aspek proses sains dapat diketahui dari penjelasan di atas, yaitu pada KI 2 dan KI 4. Hal ini menunjukkan bahwa kemampuan proses sains sangat penting agar peserta didik dapat berpikir kritis pada pembelajaran Kimia.

Sistem Koloid merupakan materi pokok kimia pada semester genap kelas XI yang memiliki karakteristik materi berupa pengetahuan faktual, konseptual dan prosedural. Pada proses pembelajaran Sistem Koloid untuk melihat kemampuan proses sains peserta didik maka digunakan metode ilmiah seperti merumuskan suatu permasalahan yang ada, merumuskan hipotesis dari permasalahan, mengumpulkan datadata, menguji hipotesis yang terbentuk sebelumnya, dan menarik suatu kesimpulan yang tepat terhadap permasalahan tersebut. Untuk melihat ketercapaian KD 2.1 dan KI 4 diperlukan aktivitas-aktivitas peserta didik dalam pembelajaran yang berdasarkan metode ilmiah yang dikenal dengan Keterampilan Proses Sains (KPS).

KPS adalah suatu kemampuan dalam pembelajaran dengan berpusat pada nilai dan sikap selama kegiatan belajar mengajar yang menuntut peserta didik untuk aktif dan kreatif dalam mendapatkan ilmu pengetahuan baru, sehingga memiliki keterampilan diri yang baik untuk diterapkan dalam kehidupan sehari-hari ${ }^{[1]}$. KPS termasuk dalam ranah psikomotorik yang merupakan penilaian lanjutan dari hasil belajar kognitif dan afektif yang pada pembelajaran kimia penilaian aspek psikomotorik dilihat dari kegiatan di kelas dan kegiatan praktikum ${ }^{[2]}$.

Penulis memperoleh informasi dari hasil tanya jawab dengan guru kimia dan pengisian angket oleh peserta didik SMAN 1 Sungayang dan SMAN 1 Lubuk Basung, bahwa KPS peserta didik belum berkembang secara optimal di sekolah tersebut. Hal ini disebabkan karena penilaian pada ranah psikomotorik kurang diperhatikan. Penilaian lebih diutamakan pada ranah kognitif, sedangkan penilaian aspek psikomotorik cenderung mengikuti hasil dari penilaian pada ranah kognitif. Hal ini berdampak pada kemunculan KPS peserta didik yang masih sedikit dalam kegiatan pembelajaran, terutama pada kegiatan praktikum.

Ranah psikomotorik merupakan ranah yang mengkaji tentang bagaimana keterampilan atau kemampuan peserta didik setelah mendapatkan ilmu pengetahuan baru dalam proses pembelajaran. Setelah belajar, peserta didik harus mampu menerapkan konsep-konsep yang didapatkan sehingga KPS menjadi bekal peserta didik untuk mendapatkan pengetahuan yang baru dengan menggunakan dan mengembangkan ilmu pengetahuan yang telah ada dengan pembelajaran dan metode ilmiah ${ }^{[3]}$.

Model pembelajaran inkuiri adalah alternatif untuk memunculkan dan mengembangkan KPS peserta $\operatorname{didik}^{[4]}$. Model pembelajaran inkuiri yang efektif digunakan salah satunya adalah Inkuiri Terbimbing (IT). Dengan pembelajaran IT, peserta didik dapat meningkatkan kemampuan berpikir secara kritis, logis, dan sistematis sehingga dapat belajar dengan aktif dan dapat menemukan konsepkonsep secara mandiri melalui pertanyaan yang diajukan ${ }^{[5]}$. Langkah model pembelajaran IT terdiri dari tahap orientasi, eksplorasi, pembentukan konsep, aplikasi, dan penutup. Pada setiap langkah model pembelajaran IT ini peserta didik dituntut untuk mengajukan pertanyaan, merumuskan hipotesis, mengumpulkan data-data, menginterpretasikan, dan menarik kesimpulan, yang mana hal tersebut merupakan indikator-indikator KPS sehingga model pembelajaran IT dapat memunculkan dan meningkatkan KPS peserta didik.

Peserta didik membutuhkan suatu bahan ajar yang dapat membantu aktivitas belajarnya. Bahan ajar yang dirancang merupakan seperangkat materi yang berguna untuk memudahkan guru mengajar dan memudahkan peserta didik memperoleh informasi dalam pelaksanaan pembelajaran ${ }^{[6]}$. KPS akan terlihat pada peserta didik yang menggunakan bahan ajar atau media yang tepat sehingga KPS peserta didik dapat muncul dan meningkat.

Modul merupakan bahan ajar dalam bentuk cetakan yang digunakan oleh guru agar peserta didik aktif dalam belajar karena modul dapat menunjang proses pembelajaran agar lebih efektif dan efisien. Penggunaan modul dalam proses belajar mengajar dapat merangsang situasi belajar yang lebih mengaktifkan peserta didik untuk memecahkan masalah-masalah di bawah pengawasan dan bimbingan guru ${ }^{[7]}$.

Modul dengan model IT sesuai dengan tuntutan pembelajaran pada kurikulum 2013 revisi 2018 yang menuntut adanya bahan ajar yang mampu melibatkan peserta didik untuk mencari, mengolah, mengkonstruksi, dan menggunakan pengetahuan dalam proses pembelajaran ${ }^{[8]}$. Modul yang menggunakan pendekatan IT dapat memperhatikan aspek-aspek KPS sehingga setelah proses pembelajaran selesai, KPS dan hasil belajar peserta didik dapat meningkat ${ }^{[9]}$.

\section{METODE}

Penelitian ini tergolong ke dalam penelitian kepustakaan (library research). Penelitian kepustakaan (library research) adalah suatu penelitian dengan menggunakan metode 
pengumpulan data pustaka, atau dengan kata lain suatu penelitian yang objek penelitiannya bersumber dari berbagai kepustakaan seperti buku, ensiklopedia, jurnal, artikel ilmiah, koran, dan majalah $^{[10]}$. Artikel yang di-review adalah artikel tentang modul kimia berbasis IT pada materi Sistem Koloid. Fokus dari penelitian kepustakaan adalah menganalisis dan menjawab rumusan masalah penelitian dengan mencari berbagai informasi tentang teori-teori, hukum-hukum, dan prinsip-prinsip, serta gagasan yang selanjutnya diolah sebagai data penelitian. Penelitian ini bersifat deskriptif, yaitu suatu uraian yang berupa penjelasan dari pemahaman yang dikemas secara teratur agar pembaca dapat memahami dengan baik.

Data sekunder adalah data yang digunakan pada penelitian ini, yaitu data yang didapatkan dari hasil penelitian yang dilakukan oleh peneliti lain sebelumnya, bukan dari pengamatan langsung peneliti. Sumber data bisa diperoleh dari buku, laporan ilmiah berupa artikel atau jurnal baik dalam bentuk cetak maupun non-cetak ${ }^{[11]}$.

Metode pengumpulan data pada penelitian ini adalah metode dokumentasi, dengan cara mencari data dari sumber yang memiliki keterkaitan dengan rumusan masalah penelitian. Data dapat berbentuk tulisan dan gambar yang telah didapatkan dari berbagai sumber ${ }^{[12]}$.

Metode analisis data dalam penelitian ini menggunakan teknik analisis isi (content analysis). Setelah semua data penelitian diperoleh, penulis menganalisis data yang telah ada untuk mendapatkan kesimpulan penelitian yang benar dan tepat. Analisis isi bersifat mendalam terhadap suatu informasi yang tertulis di media massa. Media massa yang digunakan berupa surat kabar, berita radio, iklan televisi maupun semua bahan dokumentasi lainnya ${ }^{[13]}$.

\section{HASIL DAN DISKUSI}

Penelitian yang

dilakukan oleh Andromeda et al. (2019) di Universitas Negeri Padang, Indonesia, menunjukkan bahwa materi Sistem Koloid merupakan materi yang pelaksanaan pengajarannya pada umumnya dapat dilakukan di laboratorium. Kegiatan praktikum di sekolah bagi peserta didik sangat diperlukan karena dapat memberikan peluang untuk dapat menemukan konsep, mengembangkan kemampuan kognitif, afektif, dan psikomotor para peserta didik ${ }^{[14]}$. Kegiatan praktikum juga dapat memberikan pengalaman belajar yang membuat peserta didik ikut langsung dalam pelaksanaan praktikum seperti mengamati, mempraktikkan, menanamkan, dan mengembangkan kemampuan ilmiah ${ }^{[15]}$. Penelitian di atas ini sejalan dengan penelitian yang telah dilakukan oleh Gay (2014) di Chicago State University, United States yang menyatakan bahwa kegiatan praktikum di laboratorium membuat peserta didik mengajukan lebih banyak pertanyaan, melakukan pengamatan dengan tepat, memahami langkah-langkah prosedural dengan baik dan mencoba menghubungkan teori dengan praktik ${ }^{[16]}$.

Kegiatan praktikum yang digunakan untuk melihat KPS peserta didik pada materi sistem koloid ini dirancang dalam sebuah modul dengan menggunakan model pembelajaran IT. Hasil penelitian oleh Dauglas (2012) di University of Florida, Amerika Serikat tentang proses orientasi pembelajaran IT yang diterapkan di sekolah mengindikasikan bahwa peserta didik pada pembelajaran IT memiliki hasil belajar yang lebih tinggi daripada peserta didik tanpa pembelajaran IT. Lebih tingginya hasil belajar dengan pembelajaran IT ini disebabkan oleh beberapa faktor, diantaranya metode pengajaran ${ }^{[17]}$.

Pada kelas tanpa pembelajaran IT hanya difokuskan kepada pemberian materi pembelajaran oleh guru yang kemudian peserta didik diberikan latihan soal untuk menjawab pertanyaan yang ada tentang materi pembelajaran yang telah dipelajari. Pada proses penyampaian materi, interaksi antara guru dengan peserta didik terjadi, namun tidak terjadi umpan balik terhadap masalah yang ditemukan oleh peserta didik.

Sedangkan, pada kelas dengan pembelajaran IT difokuskan kepada Lembar Kerja Peserta Didik (LKPD). Peserta didik diberikan lembar kerja pada setiap pertemuan kelas, dan mengerjakannya secara berkelompok. Dalam proses pembelajaran, guru berinteraksi dengan peserta didik di dalam kelas dengan memberikan tanggapan terhadap masalah yang ditemukan pada setiap akhir pertemuan kelas yang bertujuan untuk mengetahui pemahaman peserta didik dan membantu mereka aktif dalam pembelajaran ${ }^{[17]}$.

Faktor selanjutnya, terdapat pada penggunaan tujuan pembelajaran. Pada kelas tanpa pembelajaran IT, tujuan pembelajaran hanya disebutkan di awal pertemuan kelas untuk menjelaskan apa yang akan dipelajari oleh peserta didik. Sementara, pada kelas dengan pembelajaran IT, tujuan pembelajaran disebutkan di awal dan di akhir pertemuan kelas. Penyampaian tujuan pembelajaran di akhir pertemuan kelas ditujukan agar peserta didik mengetahui apa yang telah mereka pelajari dan dapat meninjau kembali apa yang telah mereka dapatkan dalam pembelajaran. Faktor-faktor tersebut di atas yang mengakibatkan peserta didik dengan pembelajaran IT mendapatkan hasil belajar yang lebih tinggi ${ }^{117]}$.

Dalam penelitiannya, Dauglas (2012) juga mendapatkan hasil tentang bagaimana pengalaman peserta didik di kelas eksperimen (dengan pembelajaran IT) yang didapatkan dari hasil wawancara tiga kelompok peserta didik. Dari hasil wawancara, didapatkan bahwa peserta didik menyadari manfaat bekerja dalam kelompok yaitu mendorong pemikiran kritis, meningkatkan keterampilan kerja sama, dan menyediakan kesempatan bagi setiap peserta didik untuk berkontribusi pada setiap pemecahan masalah yang ada. Peserta didik juga menyadari manfaat penggunaan lembar kerja yaitu untuk meningkatkan 
tingkat pemahaman peserta didik tentang materi pembelajaran karena selama pembahasan kelompok peserta didik secara aktif terlibat dalam pemecahan masalah dan berinteraksi dengan anggota kelompok mereka $^{[17]}$.

Keterlibatan peserta didik yang aktif dalam kegiatan praktikum dapat meningkatkan KPS. Peserta didik dengan KPS yang tinggi dapat memahami permasalahan dan memecahkan masalah secara kompleks ${ }^{[18]}$. Berdasarkan penelitian yang dilakukan oleh Gurses (2014) di Ataturk University, Turkey menunjukkan bahwa model pembelajaran IT adalah salah satu model yang tepat agar peserta didik memiliki KPS yang tinggi. Hal ini disebabkan karena model pembelajaran IT dapat membuat peserta didik memiliki keinginan belajar yang baik sehingga aktif dalam belajar dan memiliki rasa tanggung jawab ${ }^{[18]}$.

Penelitian yang dilakukan oleh Vebrianto (2011) di Universiti Kebangsaan Malaysia, Malaysia tentang media pengajaran dan pembelajaran mengungkapkan bahwa terdapat perbedaan yang signifikan pada pengetahuan KPS peserta didik yang belajar menggunakan modul dengan peserta didik yang belajar menggunakan pendekatan konvensional yaitu seperti pada Tabel 1 .

Tabel 1. Skor Rata-Rata Tes KPS ${ }^{[20]}$.

\begin{tabular}{c|c|c|c} 
Kelompok & N & $\begin{array}{c}\text { Skor } \\
\text { Rata- } \\
\text { rata }\end{array}$ & $\begin{array}{c}\text { Standar } \\
\text { Deviasi }\end{array}$ \\
\hline $\begin{array}{c}\text { Modul Multimedia/ } \\
\text { ICT }\end{array}$ & 32,00 & 81,36 & 5,00 \\
\hline Konvensional & 32,00 & 74,17 & 6,16
\end{tabular}

Tabel 1 menunjukkan skor tes rata-rata KPS peserta didik. Kelompok dengan modul multimedia $(\mathrm{R}=81,36, \mathrm{SD}=5,00)$ dan kelompok konvensional $(\mathrm{R}=74,17, \mathrm{SD}=6,16)$. Dari data di atas, menunjukkan bahwa media yang dapat meningkatkan keterampilan dan prestasi proses sains peserta didik adalah media berupa modul ${ }^{[20]}$. Penelitian tersebut sesuai dengan hasil penelitian Andromeda (2016) tentang penggunaan modul efektif terhadap peningkatan hasil belajar dan KPS peserta didik ${ }^{[21]}$. Hal ini dikarenakan bahwa media pengajaran berupa modul memiliki serangkaian kegiatan yang membuat peserta didik lebih mengembangkan KPS-nya disebabkan pada pengajaran menggunakan modul peserta didik harus mengamati, menjawab pertanyaan menunjukkan, memeriksa fakta dari konsep yang ada pada modul, yang mana kegiatan ini merupakan bagian dari $\mathrm{KPS}^{[20]}$.

Ada 10 indikator KPS yang dinilai yaitu merencanakan percobaan, mengajukan pertanyaan, merumuskan hipotesis, menggunakan alat dan bahan, mengamati, mengklasifikasikan, menafsirkan, meramalkan, menerapkan konsep, dan mengkomunikasikan hasil. Hasil penelitian KPS peserta didik pada materi Sistem Koloid yang menggunakan modul IT dapat dilihat pada Gambar 1.

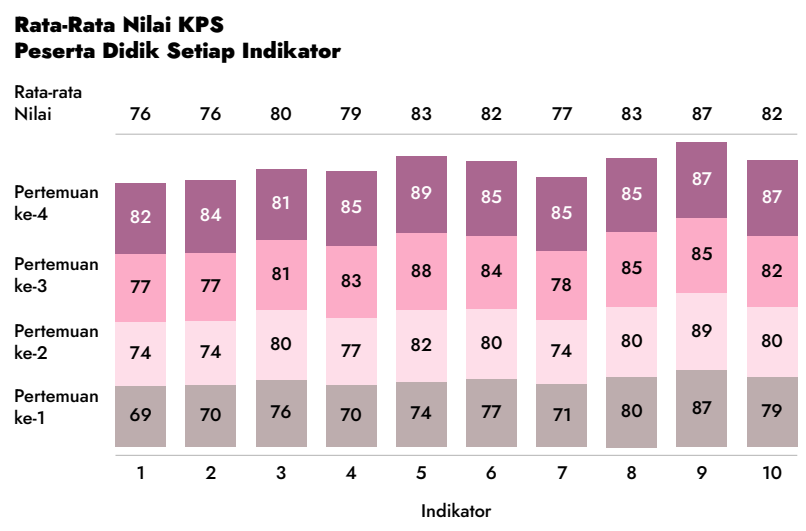

Gambar 1. Rata-rata nilai KPS peserta didik setiap indikator ${ }^{[22]}$.

Nilai rata-rata dari sepuluh indikator KPS peserta didik adalah 80,0 dengan kategori sangat baik. Hal ini menunjukkan bahwa KPS peserta didik melalui penggunaan modul Sistem Koloid berbasis IT dengan kegiatan praktikum dapat meningkatkan KPS peserta didik ${ }^{[2]}$.

Hasil penelitian yang dilakukan oleh Simsek (2010) di Marmara Üniversiy, Turkey tentang efektivitas model pembelajaran IT terhadap KPS dengan menggunakan uji T tercantum pada Tabel 2.

Tabel 2. Nilai uji T pada tes sebelum dan tes sesudah pembelajaran IT ${ }^{[19]}$.

\begin{tabular}{c|c|c|c} 
Tes & $\begin{array}{c}\text { Jumlah } \\
\text { Peserta } \\
\text { Didik }\end{array}$ & $\begin{array}{c}\text { Rata- } \\
\text { rata }\end{array}$ & $\begin{array}{c}\text { Standar } \\
\text { Deviasi }\end{array}$ \\
\hline Pre-Tes & 20,00 & 13,50 & 3,487 \\
\hline Post-Tes & 20,00 & 17,00 & 4,963
\end{tabular}

Berdasarkan data yang ada pada Tabel 2, terdapat perbedaan yang signifikan dalam KPS sebelum dan sesudah peserta didik mengikuti pembelajaran IT. Sebelum pengajaran IT, rata-rata peserta didik memiliki skor KPS sebesar 13,50. Rata-rata ini naik sebesar 3,50 menjadi 17,00 setelah pengajaran IT diberikan. Perubahan ini menunjukkan bahwa KPS peserta didik meningkat setelah melibatkan pembelajaran berbasis IT. Hal ini disebabkan peserta didik dalam pembelajaran dapat mengajukan pertanyaan, mencari penjelasan tentang pertanyaan kunci yang diberikan, membuat pemahaman tentang konsep yang mereka temukan. Indikator sub-proses ilmiah peserta didik yang meningkat setelah pengajaran IT adalah keterampilan korelasi/ klasifikasi dan keterampilan membentuk hipotesis. Skor sebelum dan sesudah pengajaran untuk keterampilan sub-proses ilmiah ini meningkat masing-masingnya dari 27 menjadi 40 dan 13 menjadi 30. Keterampilan korelasi/klasifikasi yang dimiliki oleh peserta didik yaitu 
berupa kemampuan mencari perbedaan, dan membandingkan. Keterampilan membentuk hipotesis yang dimiliki oleh peserta didik yaitu berupa kemampuan memahami bahwa suatu pernyataan berupa penjelasan harus dibuktikan kebenarannya $^{[19]}$.

Peningkatan KPS peserta didik disebabkan karena media pengajaran berupa modul dengan model pembelajaran IT ini terdiri dari 5 tahapan, yaitu orientasi, eksplorasi, pembentukan konsep, aplikasi, dan penutup. Setiap tahapannya dapat mengembangkan KPS, seperti pada tahap orientasi yang terdiri dari penyampaian indikator, tujuan pembelajaran, dan materi pendukung, peserta didik melakukan kegiatan mengamati. Tahap eksplorasi yang terdiri dari bagian presentasi model dan kegiatan praktikum, peserta didik melakukan kegiatan meramalkan, merumuskan hipotesis, dan melakukan percobaan, Tahap pembentukan konsep yang terdiri dari pertanyaan kritis, peserta didik melakukan kegiatan menerapkan konsep. Tahap aplikasi terdiri dari bagian pelatihan, peserta didik melakukan kegiatan menafsirkan, mengelompokkan, dan mengajukan pertanyaan. Tahap akhir yaitu tahap penutup terdiri dari bagian penutup, peserta didik melakukan kegiatan mengkomunikasikan hasi ${ }^{[22]}$.

Pertanyaan kritis pada tahap pembentukan konsep adalah jantung dari pembelajaran IT, peserta didik menjadi aktif untuk mempelajari konten baru dan mengembangkan keterampilan proses ${ }^{[23]}$. Dalam modul IT ini, pertanyaan kritis dirancang berdasarkan indikator-indikator KPS sehingga dapat meningkatkan minat peserta didik untuk belajar mandiri menggunakan semua kemampuan yang telah mereka miliki untuk menemukan konsep. Nilai KPS peserta didik yang tinggi akan sejalan dengan tingginya hasil belajar pada ranah kognitif. Peserta didik akan memiliki long time memory sehingga dapat terbantu dalam memahami materi pembelajaran.

\section{SIMPULAN}

Dari hasil penelitian kepustakaan yang telah dilakukan, dapat disimpulkan bahwa penggunaan modul pembelajaran IT pada materi Sistem Koloid dapat memunculkan KPS peserta didik dengan baik.

\section{REFERENSI}

1. Mulyasa. Kurikulum Berbasis Kompetensi.

Bandung: PT. Remaja Rosdakarya. 2005. 99 p.

2. Sagala. Konsep dan Makana Pembelajaran.

Bandung: Alfabeta. 2003. 160 p.

3. Rustaman. Strategi Belajar Mengajar. UM Press. 2005. 75 p.

4. Hafit, Nur. Analisis Pengembangan Karakter, Keterampilan Proses Sains, dan Penguasaan Konsep Siswa Pada Topik Koloid Melalui Pembelajaran Inkuiri Terbimbing. (2016). 8(2), 157-165.

5. Sanjaya, W. Strategi Pembelajaran Berorientasi Standar Proses pendidikan. Kencana. 2006. 196 p.
6. Hamdani. Strategi Belajar Mengajar. Pustaka Setia. 2010.

7. Depdiknas. Panduan Pengembangan Bahan Ajar. Direktorat Jendral Manajemen Pendidikan Dasar dan Menengah, Tahun 2008.

8. Arsyad A. Media Pembelajaran. Jakarta: Raja Grafindo Persada; 2013. 34 p.

9. Novilia L, Iskandar SM, Fajaroh F. Pengembangan Modul Pembelajaran dengan Pendekatan Inkuiri Terbimbing pada Materi Koloid di SMA. J Pendidik Sains. 2016;4(3):95101.

10. Syaodih. Metode Penelitian Pendidikan. Bandung: PT. Remaja Rosdakarya; 2009. 52 p.

11. Azwar S. Metode Penelitian. Yogyakarta: Pustaka Pelajar; 2009. 91 p.

12. Sugiyono. Metode Penelitian Pendidikan: Pendekatan Kuantitatif, Kualitatif dan R\&D. Bandung: Alfabeta; 2017.329 p.

13. Afifuddin. Metodologi Penelitian Kualitatif. Bandung: Pustaka Setia; 2012.165 p.

14. Ellisa L, Winarti A. Implementasi Metode Drill And Practice Berbantuan Media Question Card Pada Materi Hidrolisis Garam Terhadap Keterampilan Proses Sains Dan Hasil Belajar Siswa Kelas Xi Ipa Sma Negeri 8 Banjarmasin Implementation of Drill and Practice Method with Question C. 2019;2(3):80-6.

15. Astuti R, et.al. Pembelajaran IPA dengan Pendekatan Keterampilan Proses Sains Menggunakan Metode Eksperimen Bebas Termodifikasi danEksperimen Terbimbing Ditinjau dari Sikap Ilmiah dan Motivasi Belajar Siswa. Jurnal Inkuiri, 2012. Vol 1, No 1.

16. Van Duzor AG. Using Self-Explanations in the Laboratory to Connect Theory and Practice: The Decision/Explanation/Observation/ Inference Writing Method. J Chem Educ. 2016;93(10):1725-30.

17. Douglas EP, Chiu C-C. Process-oriented Guided Inquiry Learning in Engineering. Procedia - Soc Behav Sci. 2013.

18. Gürses A, Çetinkaya S, Doğar Ç, Şahin E. Determination of Levels of Use of Basic Process Skills of High School Students. Procedia - Soc Behav Sci. 2015;191:644-50.

19. Şimşek P, Kabapinar F. The effects of inquirybased learning on elementary students' conceptual understanding of matter, scientific process skills and science attitudes. Procedia Soc Behav Sci. 2010;2(2):1190-4.

20. Vebrianto R, Osman K. The effect of multiple media instruction in improving students' science process skill and achievement. Procedia - Soc Behav Sci. 2011.

21. Andromeda, Bahrizal, \& Zahara. Efektivitas Kegiatan Praktikum Terintegrasi dalam Pembelajaran pada Materi Kesetimabangan Kimia Kelas XI SMA/MA. Jurnal Eksakta, 2016. Volume 1 Februari 2016.

22. Andromeda, Ellizar, Iryani, Yerimadesi, Rahmah F. The effectiveness of guided inquiry 
Edukimia $\cdot 2020$ • Vol. 2, No. 3

based colloid system modules integrated experiments on science process skills and student learning outcomes. J Phys Conf Ser. 2019;1317(1).

23. Hanson DM. Designing Process-Oriented Guided-Inquiry Activities. 2005; 